\title{
Late effects of Beauveria bassiana on larval stages of Aedes aegypti Linneo, 1762 (Diptera: Culicidae)
}

\author{
Efeitos tardios de Beauveria bassiana nos estágios larvais de Aedes aegypti Linneo, 1762 \\ (Diptera: Culicidae)
}

\author{
I. Quintero-Zapata ${ }^{(\mathbb{D}}$, M. S. Flores-Gonzáleza ${ }^{(\mathbb{D})}$, E. J. Luna-Santillana ${ }^{\mathrm{b}}$ (D), N. Arroyo-Gonzálezc ${ }^{(\mathbb{D})}$ and \\ F. L. Gandarilla-Pacheco ${ }^{\mathrm{a} *}$ (iD) \\ aUniversidad Autónoma de Nuevo León, Instituto de Biotecnología, Facultad de Ciencias Biológicas, San Nicolás de los Garza, N.L. México \\ 'Instituto Politécnico Nacional, Centro de Biotecnología Genómica, Laboratorio de Medicina de Conservación, Reynosa, Tamaulipas, México \\ 'Pontificia Universidad Católica de Puerto Rico, Centro de Enseñanza e Investigación en Biotecnología y Agrobiotecnología, Ponce, Puerto Rico
}

\begin{abstract}
Aedes aegypti is a culicide that has gained relevance over the years due to its ability to transmit various viruses that cause diseases in humans that all the years cause high mortality rates in the world population. The main problem is that Ae. aegypti has managed to establish and maintain a close relationship with humans and their habitat, which is why the search for alternatives to control vector populations becomes imperative. The objective of the present work was to study the effects of two Beauveria bassiana strains on Aedes aegypti. Third instar larvae of Ae. aegypti in $250 \mathrm{~mL}$ plastic containers were inoculated with the GHA and NB3 strains at different concentrations $\left(1.5 \times 10^{4}, 1.5 \times 10^{5}, 1.5 \times 10^{6}\right.$ and $1.5 \times 10^{7}$ conidia $/ \mathrm{mL}$ ). The NB3 strain presented highest mortality values with $63 \%$ in the highest concentration i.e., $1.5 \times 10^{7}$, while for the GHA strain the highest mortality value was $30.7 \%$ at the same concentration. The results showed significant difference in mortality with respect to the strain and days post treatment $(P=0.0001)$, but not with respect to the conidial concentration $(P=0.634)$. The average mortality of larvae per day for the NB3 for different concentrations ranged from 20 to 25 larvae per day, while for the GHA daily mortality ranged from 5 to 12 larvae. In post-treatment mortality, the highest mortality was recorded in the third stage larvae for the NB3, while for GHA the highest percentage mortality was observed in individuals who managed to reach the adult state. The findings of the current research depicted the noteworthy role of $B$. bassiana for the management of an important vector of human disease.
\end{abstract}

Keywords: Ae. aegypti, B. bassiana, conidia, mortality, management, post treatment.

\begin{abstract}
Resumo
O Aedes aegypti é um culicida que vem ganhando relevância ao longo dos anos devido à sua capacidade de transmitir diversos vírus causadores de doenças em humanos que ao longo dos anos ocasionam altas taxas de mortalidade na população mundial. O principal problema é que Ae. aegypti tem conseguido estabelecer e manter uma relação próxima com o homem e seu habitat, por isso a busca por alternativas para o controle das populações de vetores torna-se imperativa. O objetivo do presente trabalho foi estudar os efeitos de duas cepas de Beauveria bassiana sobre Ae. aegypti. Larvas de terceiro instar de Ae. aegypti em recipientes plásticos de $250 \mathrm{~mL}$ foram inoculados com as cepas GHA e NB3 em diferentes concentrações $\left(1.5 \times 10^{4}, 1.5 \times 10^{5}, 1.5 \times 10^{6} \mathrm{e} 1.5 \times 10^{7}\right.$ conídios $\left./ \mathrm{mL}\right)$. A cepa NB3 apresentou os maiores valores de mortalidade com $63 \%$ na concentração mais alta, ou seja, $1.5 \times 10^{7}$, enquanto para a cepa GHA o maior valor de mortalidade foi $30.7 \%$ na mesma concentração. Os resultados mostraram diferença significativa na mortalidade com relação à cepa e dias pós-tratamento $(P=0.0001)$, mas não com relação à concentração de conídios $(P=0.634)$. A mortalidade média de larvas por dia para o NB3 para diferentes concentrações variou de 20 a 25 larvas por dia, enquanto para o GHA a mortalidade diária variou de 5 a 12 larvas. Na mortalidade pós-tratamento, a maior mortalidade foi registrada nas larvas de terceiro estágio para o NB3, enquanto para o GHA o maior percentual de mortalidade foi observado em indivíduos que conseguiram atingir o estado adulto. Os resultados da pesquisa atual retratam o papel notável de $B$. bassiana no manejo de um importante vetor de doenças humanas.
\end{abstract}

Palavras-chave: Ae. aegypti, B. bassiana, conídios, mortalidade, gestão, pós-tratamento.

\section{Introduction}

The increasing incidence and geographical distribution of arbovirosis constitutes one of the main public health problems in Americas, and in general in the entire world. In addition to the reappearance of dengue virus and yellow

*e-mail: fatimagandarilla84@gmail.com

Received: May 11, 2020 - Accepted: August 19, 2020 
fever virus, new pathogenic arboviruses formerly confined to specific regions of the world, such as the chikungunya and Zika viruses, have recently caused various pandemics with significant morbidity. Mosquitoes are considered the most important vectors of human diseases, specifically Aedes aegypti Linneo, 1762 (Diptera: Culicidae) is a culicid capable of transmitting dengue, chikungunya, Zika and mayaro fever, and of these pathologies the one with the highest incidence is dengue.

A recent report estimates that 390 million cases occur each year worldwide, of which 96 million have clinical manifestations. Another study estimates that 3.9 billion people from 128 countries are at risk of dengue virus infection. Only in the year 2019 in America the total number of dengue cases was 2,981,769 according to reports from the Pan American Health Organization (Espinal et al., 2019; Evans et al., 2018; PAHO, 2020). For this, part of the solution to this problem lies in implementing strategies to prevent and control the spread of the vector of these arboviruses, however, there are factors that can create hurdles, including social determinants, climate change, demographic aspects, deficiencies in the epidemiological surveillance system at the laboratory level, as well as the same surveillance and control of the spread of the mosquito (México, 2014).

The control of Ae. aegypti continues to be with the only effective measure to reduce the emergence and transmission of these diseases. Historically the control of the mosquito has been carried out through the use of synthetic larvicides or adulticides, due to its low cost. The excessive use has propitiated the acquisition of resistance gradually in mosquitoes, in addition to residuality in the environment (Pérez, 2017). The problem caused by the insect's activities is enormous and requires comprehensive strategies to control it. These types of strategies propose considering different methods to achieve successful mosquito management, such as environmental sanitation, chemical and biological control, and the introduction of genetic engineering methods. Biological control agents are considered suitable alternatives to the use of insecticides because the biocontrol agents are host specific and safe for the environment and humans. Although biological control is not immediate, it is more feasible and sustainable in the long term compared to the chemical control (McClintock et al., 2000). For the biological control of mosquitoes, the use of fish, nematodes, planarians, beetles, anurans, bacteria and fungi have been reported (Rawal, 2019).

Entomopathogenic fungi are potential agents for pest control due to their host specificity, wide host range, mode of action, and ease of production and application (Dhaliwal and Koul, 2011). In the specific case of Beauveria bassiana, which is considered a cosmopolitan fungus, its natural occurrence on mosquitoes is not very common and has been reported on rare occasions. However, since the late sixties the importance of this fungus for the control of Ae. aegypti was recognized (Clark et al., 1968). Recent studies have shown the potential of entomopathogenic fungi for the control of vector mosquitoes (Garcia-Munguía et al., 2011; Bitencourt et al., 2018; Carolino et al., 2019). In the case of fungi, as in that of other pest control agents effectiveness is measured by its virulence and in other cases by its lethality, however, the efficiency of a control agent on its target could be subject to many more conditions, since it is known that not all insects treated with a fungal agent necessarily they will die immediately after application (GandarillaPacheco et al., 2015). This phenomenon has been called sublethal effects or late effects at different stages of the mosquito life cycle which gives them a selective advantage over other agents similar to them (Mnyone et al., 2011; Pelizza et al., 2013; Portilla et al., 2017). These effects are considered relevant because in insects such as Ae. aegypti, which is holometabolo, this type of study helps to elucidate which stage of the insect's life cycle would be the most suitable for the application of the fungal agent. Therefore, the objective of this study was to determine the pathogenicity of two strains of $B$. bassiana on larvae of Ae. aegypti, as well as establishing the effect on its life cycle.

\section{Material and Methods}

\subsection{Aedes aegypti}

Ae. aegypti eggs were obtained from the insect breeding area of the Biotechnology Institute - UANL. To obtain larvae, papers ballots impregnated with eggs were placed in a plastic container with 4 liters of water and $0.5 \mathrm{~g}$ of fish food. The containers were incubated for 48 hours at $30^{\circ} \mathrm{C}$ to stimulate hatching.

\subsection{Microorganisms}

Fungal isolates were obtained from a collection at the L-6 laboratory of the Biotechnology Institute (strains NB3 y GHA) and each strain was cultured on Sabouraud dextrose agar media and incubated for 14 days at $25 \pm 2{ }^{\circ} \mathrm{C}$.

\subsection{Preparation of suspensions for bioassays}

After the incubation time, $10 \mathrm{~mL}$ of Tween 80 solution at $0.1 \%(\mathrm{v} / \mathrm{v})$ was added, and the surface of each plate was scraped with a spreader to obtain a concentrated suspension of conidia. A Neubauer chamber was used to determine the concentration of the suspensions, and each suspension was adjusted to different concentrations $\left(1.5 \times 10^{4}, 1.5 \times 10^{5}, 1.5 \times 10^{6}\right.$ and $1.5 \times 10^{7}$ conidia $\left./ \mathrm{mL}\right)$.

\subsection{Evaluation of conidia viability}

The conidial viability at the time of treatment by $1-\mathrm{ml}$ aliquots of conidia suspension onto potato dextrose agar in Petri dishes (10-cm diameter) and incubating for 18 hours at $25^{\circ} \mathrm{C}$. Spore germination was halted by placing three drops of lactophenol cotton blue and adding a coverslip over a stain droplet on a microscope slide. The percentage of viable conidia was determined by examining 100 conidia in each of three fields of view at 400X magnification with the aid of a compound microscope and determining the number of conidia that had a distinct germ tube as defined by germ tube length twice the diameter of the conidia (Goettel and Inglis, 1997). The conidial suspensions were used immediately for bioassays. 


\subsection{Bioassays}

Third-instar larvae of Ae. aegypti were used for inoculation. Twenty-five larvae per replication were put in sterile plastic $200-\mathrm{ml}$ containers with $143 \mathrm{~mL}$ of sterile double distilled water and $7 \mathrm{~mL}$ of conidial suspension for each treatment. Two control treatments were included, one with $0.1 \%$ Tween 80 solution (v/v) and one absolute (not treated). Dead larvae were counted every 24 hours for 10 consecutive days. The dead larvae were put into a humidity chamber to stimulate mycosis $\left(25 \pm 2^{\circ} \mathrm{C} ; 85 \%\right.$ R.H. $)$.

\subsection{Biological cycle of surviving post treatment larvae}

From day 11, the larvae that survived the bioassay were observed daily for any morphological changes in their life cycle, larval, pupal or adult status. With these data, the percent survival, mortality and changes in stages after treatment were determined.

\subsection{Statistical analysis}

The experiments were performed in randomized design. The data were analyzed using analysis of variance and comparisons of means (Tukey's test) at a 5.0\% probability level with the SPSS ${ }^{\circledR}$ (version 19, IBM ${ }^{\circledR}$, New York). The Kolmogorov-Smirnov test was used to verify normality of data. Arcsine transformed mortality and survival rates were expressed as a percentage with confidence interval of $95 \%$.The experiment was repeated twice under the same conditions.

\section{Results and Discussion}

\subsection{Mortality}

The mortality recorded for the GHA and NB3 strains at the different concentrations on the larval stages of Ae. aegypti at ten days of incubation are summarized in Figure 1 . The NB3 strain presented the highest mortality values with $63 \%$ in the concentration $1.5 \times 10^{7}$ conidia $/ \mathrm{mL}$, while for the GHA strain the highest mortality value was $30.7 \%$ at the same concentration. The data a significant difference in mortality with respect to the strain and the day $(P=0.0001)$, but not with regard to the conidial concentration $(P=0.539)$. The average mortality of larvae per day for the NB3 strain between different concentrations ranged from 20 to 25 dead larvae per day, while for the

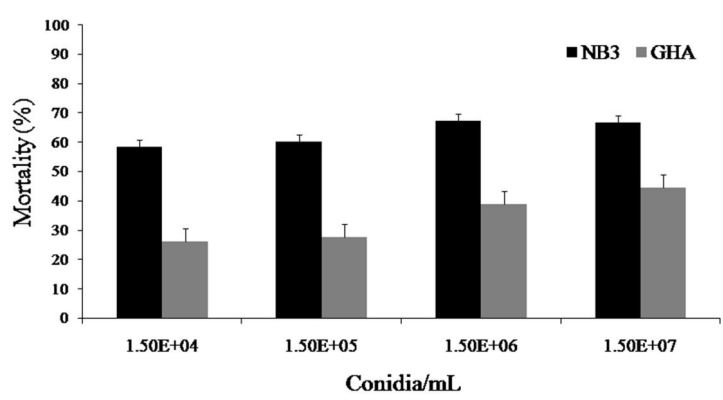

Figure 1. Mortality of $3^{\text {rd }}$ instar Aedes aegypti larvae by conidia of Beauveria bassiana under laboratory conditions $\left[25 \pm 2^{\circ} \mathrm{C} ; 12: 12 \mathrm{~h}\right.$ (light: darkness)] at ten days of incubation.
GHA strain the average daily mortality ranged from 5 to 12 larvae. Control treatments did not show mortality.

In the case of entomopathogenic fungi, there are various and varied methodologies that have been tested for the control of mosquitoes (Tejeda-Reyes et al., 2018). In this study, two strains of $B$. bassiana (NB3 and GHA) were tested by immersion for the control of third-instar larvae of Ae. aegypti. The results obtained showed that NB3 strain was more potent to cause mortality during the ten days than the GHA strain. These results partially coincide with those reported in another study where a Peruvian strain of $B$. bassiana generated a mortality pattern consistent with concentrations of the order of $10^{6}-10^{7}$ conidia / mL, however, in the aforementioned study, mortality depended on the amount of spores infecting the larva not from time (Alcalde-Mosqueira et al., 2014), while in this study mortality did not depend on the conidia concentration, but on time. In the case of Ae. aegypti the normal life cycle is reported to last between 10 to 14 days from hatching of the egg until the incidence of adult emergence, coinciding with the time of the infective cycle of entomopathogenic fungi such as B. bassiana. In this scenario, a fungus capable of infecting in the shortest possible time would be more important to achieve success. For example, it has been observed that certain species of susceptible insects are prone to infection soon after molting, if the infection occurs shortly before molting, the mycelium may lost within the molt and be ineffective in causing infection (Scholte et al., 2004). It is therefore crucial to select larvae that have just molted to avoid this situation. However, it should also be considered that between isolates or strains of the same fungus there could be significant variations in their ability to cause mortality due to a natural variation in their virulence (Valero-Jimenez et al., 2014; Coates et al., 2002). In similar studies, $B$. bassiana tested on second instar larvae of Ae. aegypti at different concentrations $\left(10^{4}-10^{8}\right.$ conidia $/ \mathrm{mL}$ ) showed the mortality ranging from $12-60 \%$ (Misra et al., 2015), while in another study, second instar larvae of Ae. aegypti after infection with suspension of $1 \times 10^{7}$ conidia / mL showed a mortality of $42.56 \%$ (Bitencourt et al., 2018). After a 24-hour incubation period, the recovered dead larvae showed a reddish coloration, and after 48 hours of incubation the growth of the fungus was seen on the external surface of insect. The presence of this coloration indicates the involvement of secondary metabolites or toxins that participated in concomitance to cause the death of the insect, specifically oosporein, which has antibiotic properties giving the characteristic coloration to the body. The main function of this compound is to prevent the growth of bacteria, allowing the development of the entomopathogen. Furthermore, these compounds have the characteristic of evading the insect's immune system (Berlanga-Padilla et al., 2016).

\subsection{Biological cycle of surviving post treatment larvae}

Regarding post-treatment survival, at the lowest concentration the highest percentage of survival was recorded for both strains, while the lowest survival rate was recorded for GHA at the concentration of $10^{7}$ (Table 1). In post-treatment mortality, the highest rate of 
mortality was recorded in the third instar larvae for NB3 (Table 2), while for GHA the highest percent mortality was observed in the larvae who managed to reach the adult stage (Table 3), while there was no significant difference in post-treatment mortality with respect to the strain $(P=0.266)$ and concentration $(P=0.538)$ of conidia used. On the other hand, a significant difference $(P=0.028)$ after treatment according to the larval stage of Ae. aegypti was recorded (Figure 2). Average daily mortality was slightly higher for the GHA compared to the NB3 (Table 4). In contrast to the NB3, for the GHA there were no survivors for the lower concentrations $\left(10^{4}-10^{5}\right.$ conidia $/ \mathrm{mL}$ ) which may be due to the fact that for this particular strain the time of exposure to the treatment is more important than the concentration, which agrees with the statistical analysis corresponding to the dead larvae per day, where a higher mortality rate was observed on the sixth day post treatment. For this strain the highest mortality rate was recorded in the fourth stage, however, in the highest concentration it was observed that number of individuals managed to reach the adult state and survive up to 16 days. Regarding the mortality of the surviving individuals after treatment, the highest percentages were recorded in the third stage larvae treated with the
NB3. This finding is important since it indicates that the fungus was able to stop the development of the insect and died without changing its stage. In the normal cycle of Ae. aegypti, the change of instar from third to fourth normally takes one day, whereas for NB3, the larvae that managed to survive took 18-29 days to reach instar fourth, since the most died in the third instar due to the

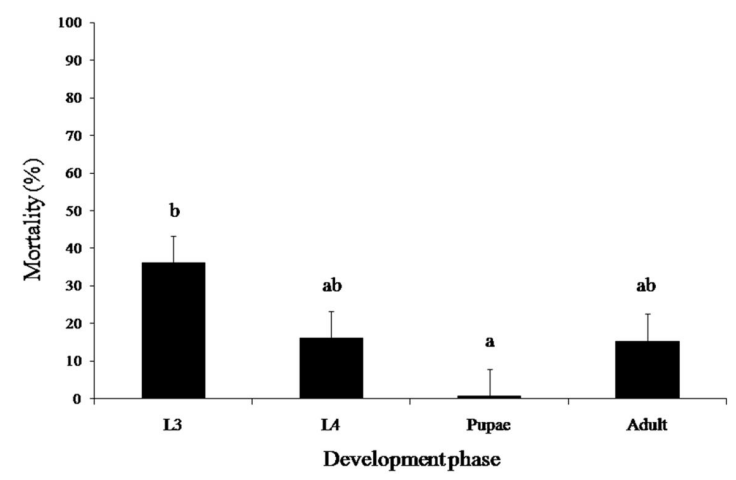

Figure 2. Mortality of Aedes aegypti larvae by conidia of Beauveria bassiana (NB3 and GHA strain) in different development phase under laboratory conditions $\left[25 \pm 2{ }^{\circ} \mathrm{C} ; 12: 12 \mathrm{~h}\right.$ (light: darkness). Treatments with different letters are significantly different $(\mathrm{p} \leq 0.05)$.

Table 1. Survival of larvae (95\% CI) of Aedes aegypti treated with strains of Beauveria bassiana under laboratory conditions $\left[25 \pm 2{ }^{\circ} \mathrm{C}\right.$; 12:12 h (light: darkness)].

\begin{tabular}{ccc}
\hline Concentrations & NB3 & GHA \\
\hline $1.50 \times 10^{4}$ & $30.65(30.533-30.767)$ & $31.94(31.891-31.989)$ \\
$1.50 \times 10^{5}$ & $27.27(27.176-27.364)$ & $30(29.102-30.898)$ \\
$1.50 \times 10^{6}$ & $26.56(26.467-26.653)$ & $27.97(27.091-28.849)$ \\
$1.50 \times 10^{7}$ & $27.97(27.875-28.065)$ & $23.57(22.739-24.401)$ \\
$*$ Mean \pm SE & $28.11 \pm 0.89$ & $28.37 \pm 1.79$ \\
\hline
\end{tabular}

${ }^{*}$ Average and standard error is reported in percentage (\%).

Table 2. Mortality by instar (95\% CI) of Aedes aegypti by effect strain NB3 under laboratory conditions $\left[25 \pm 2{ }^{\circ} \mathrm{C} ; 12: 12 \mathrm{~h}\right.$ (light: darkness)].

\begin{tabular}{ccccc}
\hline Concentrations & L3 & L4 & Pupae & Adult \\
\hline $1.50 \times 10^{4}$ & $62.02(61.069-62.971)$ & $26.56(25.695-27.425)$ & 0 & $5.73(5.275-6.185)$ \\
$1.50 \times 10^{5}$ & $78.46(77.655-79.265)$ & 0 & 0 & 0 \\
$1.50 \times 10^{6}$ & $68.86(67.953-69.767)$ & $9.97(9.383-10.557)$ & 0 & 0 \\
$1.50 \times 10^{7}$ & $58.69(57.725-59.655)$ & $17.45(16.707-18.193)$ & 0 & $23.57(22.739-24.401)$ \\
$*$ Mean \pm SE & $67.00 \pm 4.36$ & $13.49 \pm 5.63$ & 0 & $7.32 \pm 5.58$ \\
\hline
\end{tabular}

${ }^{*}$ Average and standard error is reported in percentage (\%). L3 = 3rd instar larva; L4 = 4th instar larva.

Table 3. Mortality by instar ( $95 \% \mathrm{CI}$ ) of Aedes aegypti by effect strain GHA under laboratory conditions $\left[25 \pm 2{ }^{\circ} \mathrm{C} ; 12: 12 \mathrm{~h}\right.$ (light: darkness)].

\begin{tabular}{ccccc}
\hline Concentrations & L3 & L4 & Pupae & Adult \\
\hline $1.50 \times 10^{4}$ & - & - & - & - \\
$1.50 \times 10^{5}$ & - & - & - & - \\
$1.50 \times 10^{6}$ & $3.62(3.254-4.280)$ & $49.02(48.041-49.999)$ & 0 & $37.46(36.512-38.408)$ \\
$1.50 \times 10^{7}$ & $17.45(16.707-18.193)$ & $25.84(24.983-26.697)$ & $5.73(5.275-6.185)$ & $56.16(55.188-57.132)$ \\
$*$ Mean \pm SE & $5.26 \pm 4.14$ & $18.71 \pm 11.79$ & $1.43 \pm 1.43$ & $23.40 \pm 14.04$ \\
\hline
\end{tabular}

${ }^{*}$ Average and standard error is reported in percentage (\%). L3 = 3rd instar larva; L4 = 4th instar larva. 
Table 4. Daily percentages of Aedes aegypti larval mortality by strains of Beauveria bassiana under laboratory conditions $\left[25 \pm 2^{\circ} \mathrm{C}\right.$; 12:12 h (light: darkness)].

\begin{tabular}{|c|c|c|}
\hline \multirow[t]{2}{*}{ Day } & \multicolumn{2}{|c|}{ Strain } \\
\hline & NB3 & GHA \\
\hline 1 & $1.25^{\mathrm{a}}$ & $0.00^{\mathrm{a}}$ \\
\hline 2 & $2.50^{\mathrm{a}}$ & $5.25^{a b}$ \\
\hline 3 & $1.50^{\mathrm{a}}$ & $3.25^{\mathrm{ab}}$ \\
\hline 4 & $6.50^{a}$ & $2.75^{\mathrm{a}}$ \\
\hline 5 & $33.25^{b}$ & $13.75^{a b}$ \\
\hline 6 & $35.75^{b}$ & $17.75^{b}$ \\
\hline 7 & $35.25^{\mathrm{b}}$ & $11.50 \mathrm{ab}$ \\
\hline 8 & $33.00^{\mathrm{b}}$ & $6.75^{a b}$ \\
\hline 9 & $35.00^{\mathrm{b}}$ & $6.00^{a b}$ \\
\hline 10 & $44.75^{b}$ & $11.00 \mathrm{ab}$ \\
\hline${ }^{*}$ Mean \pm SE & $8.84 \pm 1.90$ & $9.94 \pm 2.77$ \\
\hline
\end{tabular}

Treatments with different letter are statistically different (Tukey $\mathrm{p} \leq 0.05)$. *Average and standard error is reported in percentage (\%). fungus. Regarding the larvae that managed to reach fourth instar, took 5-36 days and once they were able to reach the pupa, the change to the adult stage was considerably fast (only 1-3 days), almost similar to the normal cycle of Ae. aegypti, with the only difference that the individuals that reached the adult stage only managed to survive for 1-3 days (Figure 3). The symptoms observed in the surviving stages are consistent with previous reports including behavioral changes, specifically reduced mobility and late response to light exposure. In the same way, other secondary effects are mentioned as a result of exposure to the suspensions, mechanical damage is found as a consequence of the ingestion of conidia and their establishment in the digestive system (Pereira et al., 2009). Entomopathogenic fungi can be used in a more efficient way if the impacts on the life cycle of the mosquito are known, and it is considered that the analysis of the life cycle of the insect can help to determine the best time and the stage on which the entomopathogens should be applied (Shoukat et al., 2020).

In the case of GHA, the time from hatching to third instar of the cycle lasted for 4 days, a shorter period of

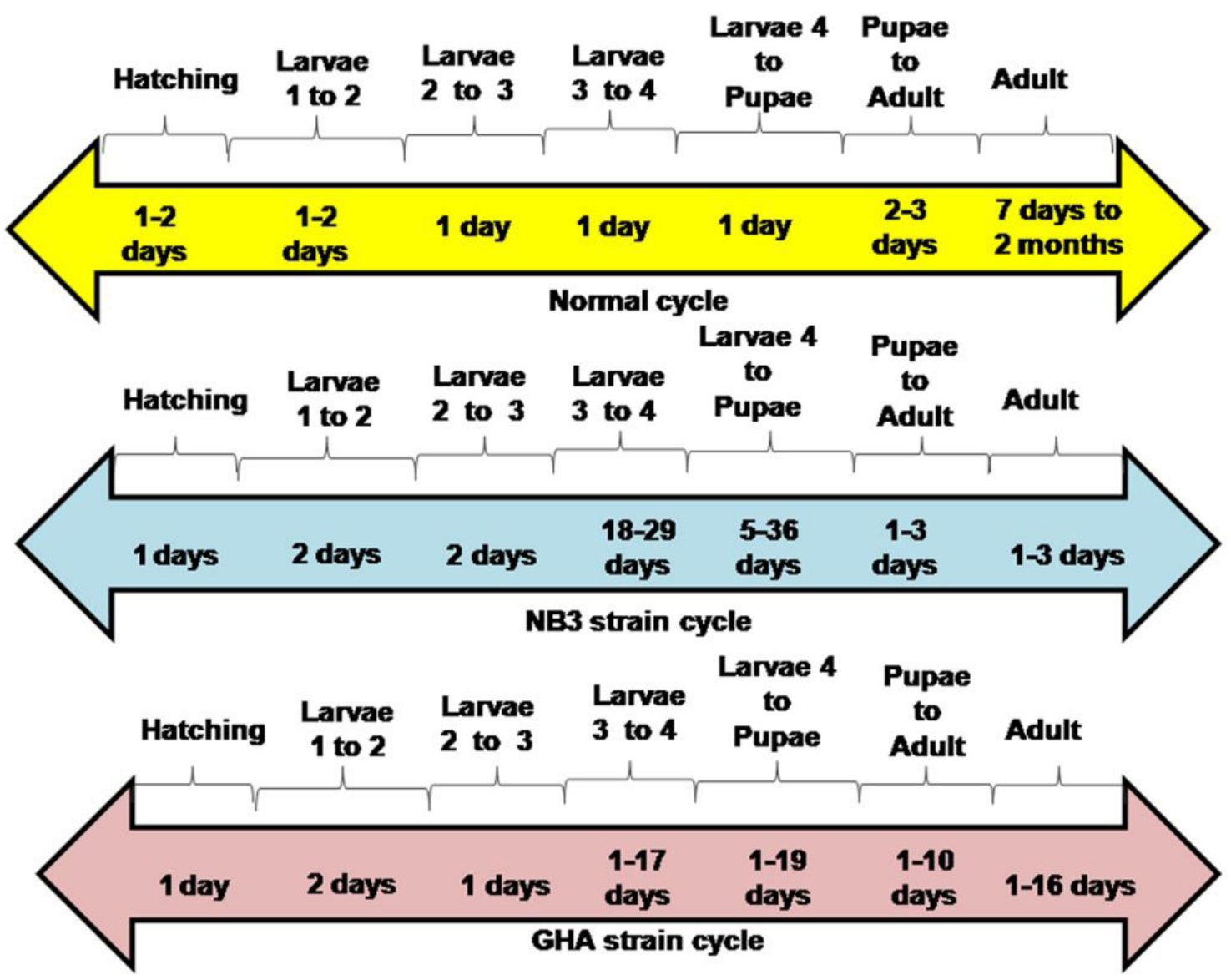

Figure 3. Biological cycle of Ae. aegypti, phase to phase time contrast in the survivors of the tested strains and the daily cycle according to the literature under laboratory conditions $\left[25 \pm 2{ }^{\circ} \mathrm{C} ; 12: 12 \mathrm{~h}\right.$ (light: darkness)]. 
time in contrast to the larvae for the test with the NB3 strain, once the bioassay was completed, the survivors remained alive for 14 days. In the review of metamorphosis, the development towards fourth instar was recorded between 1-17 days, the residence time at that stage and its change to pupa occurred between 1-10 days; from pupa to adult between 1-16 days. The post-test cycle time was shorter in contrast to surviving larvae of the NB3 strain; however, the lifetime of the last stage, the adult, was longer for the GHA strain with 1 to 16 days alive (Figure 3 ). This prolongation in the life cycle of the mosquito may be due to the process followed by the fungus once it penetrates the cuticle of the insect, affecting the fat reserves, which causes the depletion of energy resources and directly influences the change of stage, which it is reflected as a prolonged duration of larvae and pupae (Hussain et al., 2009). These effects have been mainly documented in Lepidoptera such as Heliothis zea, Lymantria dispar, Ocinaria varians, Spodoptera exigua and Helicoverpa zea (Mitchell and Cali, 1994; Henn and Solter, 2000; Hussain et al., 2009; Gandarilla-Pacheco et al., 2015), although studies have also been reported in Diptera such as Musca domestica, Culex pipiens and Anastrepha ludens (Lecuona et al., 2005; Gandarilla-Pacheco et al., 2018; Shoukat et al., 2018). In the particular case of B. bassiana, the hyphae absorb the sugar content of the insect's hemolymph, which contributes to host weakness and disrupts various biological parameters. In a study, the composition of the Bombyx mori hemolymph was detailed, in addition to comparing it with that of Galleria mellonella and Gilpinia hercyniae, the results showed the presence of amino acids, sugars and phosphorus (Wyatt et al., 1956). In a more recent study, hemolymph of fourth and fifth instar nymphs of $D$. citri was analyzed. The results obtained showed that nymphs reared in sweet orange seedlings previously infected with Candidatus Liberibacter asiaticus resulted in higher levels of various metabolites, mainly those of the tricarboxylic acids cycle, C16 and C18 fatty acid cycle, glucose, sucrose, L-proline, L-serine, pyroglutamic acid, saccharic acid, threonic acid and myo-inositol compared to nymphs raised in healthy plants. In contrast, nymphs directly infected with the bacteria were lower in putrescine, glycine, L-phenylalanine, L-tyrosine, L-valine, and chiro-inositol (Killiny and Jones, 2018). These findings demonstrate that the balance in hemolymph composition in insects of different orders can be easily altered by the interaction with pathogens and / or the stage of development in which the host is. Trehalose is considered the sugar for excellence in the hemolymph of insects, but in the case of D. citri, G. mellonella, B. mori and G. hercyniae, the glucose is considered to be dominant sugar in hemolymph. Trehalose is a glucose dimer that is formed in the intestines of insects to reduce osmotic pressure and is the first source of carbohydrate energy used for flight (Reyes de la Torre et al., 2012). When trehalose levels in hemolymph reach optimal levels, the excess is derived to the fatty body for storage as triglycerides (Arrese and Soulages, 2010). In this study, adults survivors treated with the NB3 strain only survived a maximum of 3 days, while those treated with the GHA strain survive up to 16 days. In a recent study, the effect on the biological cycle of
Aedes albopictus of filial and first filial generations treated with lethal and sublethal concentrations of $B$. bassiana observed prolonged duration of the larva and the pupa followed by a reduction in the longevity of the male and female adults (Shoukat et al., 2020). The results of this study show the importance of the late effects caused by the application of strains of $B$. bassiana on larvae of Ae. aegypti. These effects on insects such as Ae. aegypti are considered particularly important because, if the fungus is not capable of killing or eliminating the larvae of Ae. aegypti in its entirety, but if it manages to prevent them from changing stage and truncates their biological cycle, this is important because the insect will not reach the adult stage, which is infective in the case of females due to its feeding activities, and in the case of males, by preventing them from reaching the adult stage, it can help reduce fertilization.

\section{Acknowledgements}

The authors appreciate the funding granted through the Scientific and Technological Research Support Program (PAICYT) sponsored by the Autonomous University of Nuevo León (UANL), key PAICYT CN1221-20.

\section{References}

ALCALDE-MOSQUEIRA, J.G.M., ROLDÁN, J.E., SARAVIA, V.P. and COLLANTES, L., 2014. Efecto biocida de diferentes concentraciones de Metarhizium anisopliae CCB-LE302 y Beauveria bassiana CCB-LE265 sobre larvas III de Aedes aegypti. UCV-Scientia, vol. 6, no. 1, pp. 33-41. https://dialnet.unirioja. es/servlet/articulo?codigo $=6181540$

ARRESE, E.L. and SOULAGES, J.L., 2010. Insect fat body: energy, metabolism, and regulation. Annual Review of Entomology, vol. 55, no. 1, pp. 207-225. http://dx.doi.org/10.1146/annurevento-112408-085356. PMid:19725772.

BERLANGA-PADILLA, A.M., AYALA-ZERMEÑO, M.A., MONTESINOSMATÍAS, R. and RODRÍGUEZ-RODRÍGUEZ, J.C., 2016. Manual de exploración para la colecta de hongos entomopatógenos. Tecomán, Colima, México: Centro Nacional de Referencia de Control Biológico, Dirección General de Sanidad Vegetal/ SAGARPA-SENASICA. 54 p.

BITENCOURT, R.O.B., FARIAS, F.S., FREITAS, M.C., BALDUINO, C.J.R., MESQUITA, E.S., CORVAL, A.R.C., GÔLO, P.S., PONTES, E.G., BITTENCOURT, V.R.E.P. and ANGELO, I.C., 2018. In vitro control of Aedes aegypti larvae using Beauveria bassiana. International Journal of Bioengineering Life Sciences, vol. 12, no. 10, pp. 400404. http://dx.doi.org/10.5281/zenodo.1474974.

CAROLINO, A.T., GOMES, S.A., PONTES TEODORO, T.B., MATTOSO, T.C. and SAMUELS, R.I., 2019. Aedes aegypti pupae are highly susceptible to infection by Metarhizium anisopliae blastospores. Journal of Pure E'Applied Microbiology, vol. 13, no. 3, pp. 16291634. http://dx.doi.org/10.22207/JPAM.13.3.36.

CLARK, T.B., KELLEN, W., FUKUDA, T. and LINDEGREN, J.E., 1968. Field and laboratory studies on the pathogenicity of the fungus Beauveria bassiana to three genera of mosquitoes. Journal of Invertebrate Pathology, vol. 11, no. 1, pp. 1-7. http://dx.doi. org/10.1016/0022-2011(68)90047-5. PMid:5654770.

COATES, B.S., HELLMICH, R. and LEWIS, L., 2002. Allelic variation of Beauveria bassiana (Ascomycota: Hypocreales) minisatellite 
is independent of host range and geographic origin. Genome, vol. 45, no. 1, pp. 125-132. http://dx.doi.org/10.1139/g01-132. PMid:11908654.

DHALIWAL, G.S. and KOUL, O., 2011. Biopesticide and pest management: Conventional and biotechnological approaches. New Delhi: Kalyani Publishers, 455 p.

ESPINAL, M.A., ANDRUS, J.K., JAUREGUI, B., HULL WATERMAN, S., MORENS, D.M., SANTOS, J.I., HORSTICK, O., AYANA FRANCIS, L. and OLSON, D., 2019. Emerging and reemerging Aedestransmitted arbovirus infections in the Region of the Americas: implications for Health Policy. American Journal of Public Health, vol. 109, no. 3, pp. 387-392. http://dx.doi.org/10.2105/ AJPH.2018.304849. PMid:30676796.

EVANS, H.C., ELLIOT, S.L. and BARRETO, R.W., 2018. Entomopathogenic fungi and their potential for the management of Aedes aegypti (Diptera: Culicidae) in the Americas. Memorias do Instituto Oswaldo Cruz, vol. 113, no. 3, pp. 206-214. http://dx.doi. org/10.1590/0074-02760170369. PMid:29412361.

GANDARILLA-PACHECO, F.L., ELÍAS-SANTOS, M., FLORES-GONZÁLEZ, M.S., DE LUNA-SANTILLANA, E.J. and QUINTERO-ZAPATA, I., 2018. Virulencia de blastosporas de Isaria fumosorosea nativas del noreste de México sobre Anastrepha ludens(Diptera: Tephritidae). Revista Colombiana de Entomologia, vol. 44, no. 2, pp. 187-192. http://dx.doi.org/10.25100/socolen.v44i2.7316.

GANDARILLA-PACHECO, F.L., FLORES-GONZÁLEZ, M.S., MORALESRAMOS, L.H., ELÍAS-SANTOS, M., GALÁN-WONG, L.J. and QUINTERO-ZAPATA, I., 2015. Effect of Native Mexican Isolates of Isaria fumosorosea (Wize) Brown \& Smith on Spodoptera exigua (Hübner) and Helicoverpa zea (Boddie). Southwestern Entomologist, vol. 40, no. 4, pp. 721-729. http://dx.doi. org/10.3958/059.040.0411.

GARCÍA-MUNGUÍA, A.M., GARZA-HERNÁNDEZ, J.A., REBOLLARTÉLLEZ, E.A., RODRÍGUEZ-PÉREZ, M.A. and REYES-VILLANUEVA, F., 2011. Transmission of Beauveria bassiana from male to female Aedes aegypti mosquitoes. Parasites E Vectors, vol. 4, pp. 24. http://dx.doi.org/10.1186/1756-3305-4-24. PMid:21352560.

GOETTEL, M.S. and INGLIS, G.D., 1997. Fungi: hyphomycetes. In: L.A. Lacey, ed. Manual of techniques in insect pathology. San Diego, CA: Academic Press, Inc., pp. 213-249. http://dx.doi. org/10.1016/B978-012432555-5/50013-0.

HENN, M.W. and SOLTER, L.F., 2000. Food utilization values of gypsy moth Lymantria dispar(Lepidoptera: Lymantriidae) larvae infected with the microsporidium Vairimorpha sp. (Microsporidia: Burenellidae). Journal of Invertebrate Pathology, vol. 76, no. 4, pp. 263-269. http://dx.doi.org/10.1006/jipa.2000.4977. PMid:11112371.

HUSSAIN, A., TIAN, M.Y., HE, Y.R. and AHMED, S., 2009. Entomopathogenic fungi disturbed the larval growth and feeding performance of Ocinara varians(Lepidoptera: Bombycidae) larvae. Insect Science, vol. 16, no. 6, pp. 511-517. http://dx.doi. $\operatorname{org} / 10.1111 / \mathrm{j} .1744-7917.2009 .01272 . x$.

KILLINY, N. and JONES, S.E., 2018. Metabolic alterations in the nymphal instars of Diaphorina citri induced by Candidatus Liberibacter asiaticus, the putative pathogen of huanglongbing. PLoS One, vol. 13, no. 1, pp. e0191871. http://dx.doi.org/10.1371/ journal.pone.0191871. PMid:29370262.

LECUONA, R.E., TURICA, M., TAROCCO, F. and CRESPO, D.C., 2005. Microbial control of Musca domestica (Diptera: Muscidae) with selected strains of Beauveria bassiana. Journal of Medical Entomology, vol. 42, no.3, pp. 332-336. http://dx.doi.org/10.1093/ jmedent/42.3.332. PMid:15962783.

MCCLINTOCK, J.T., VAN-BEEK, N., KOUGH, J.L., MENDELSOHN, M.L. and HUTTON, P.O., 2000. Regulatory aspects of biological control agents and products derived by biotechnology, In: J.E. RECHCIGL and N.A. RECHCIGL, eds. Biological and biotechnological control of insect pests. Boca Raton: Lewis Publishers, vol. 1, pp. 305-357.

MÉXICO. GOBIERNO. SECRETARIA DE SALUD, 2014 [viewed 4 April 2020]. Prevención y Control de Dengue 2013-2018. Programa Sectorial de Salud [online]. Available from: https://www. gob.mx/salud/documentos/programa-de-accion-especificoprevencion-y-control-de-dengue-2013-2018

MISRA, K., DEKA, A.C., HAQUE, Y., RAJEEV, Y., PURKAYASTHA, S., NARAH, M., DEKA, J. and KALITA, J.C., 2015. Biocontrol potentiality of entomopathogenic fungi against larvae of dengue fever vector, Aedes aegypti (Diptera: Culicidae). Journal of Bioresources, vol. 2, no. 1, pp. 16-22. https://www.researchgate. net/publication/281114024_Biocontrol_Potentiality_of_ Entomopathogenic_Fungi_against_larvae_of_Dengue_Fever_ Vector_Aedes_aegypti_Diptera_Culicidae

MITCHELL, M.J. and CALI, A., 1994. Vairimorpha necatrix (Microsporida: Burenellidae) affects growth and development of Heliothis zea(Lepidoptera: Noctuidae) raised at various temperatures. Journal of Economic Entomology, vol. 87, no. 4, pp. 933-940. http://dx.doi.org/10.1093/jee/87.4.933.

MNYONE, L.L., KIRBY, M.J., MPINGWA, M.W., LWETOIJERA, D.W., KNOLS, B.G., TAKKEN, W., KOENRAADT, C.J. and RUSSELL, T.L., 2011. Infection of Anopheles gambiae mosquitoes with entomopathogenic fungi: effect of host age and blood-feeding status. Parasitology Research, vol. 108, no. 2, pp. 317-322. http:// dx.doi.org/10.1007/s00436-010-2064-y. PMid:20872014.

PAN AMERICAN HEALTH ORGANIZATION - PAHO, 2020 [viewed 4 April 2020]. Reported cases of dengue fever int the Americas [online]. Available from: https://www.paho.org/data/index. php/en/mnu-topics/indicadores-dengue-en/dengue-nacionalen/252-dengue-pais-ano-en.html

PELIZZA, S.A., SCORSETTI, A.C., and TRANCHIDA, M.C., 2013. The sublethal effects of the entomopathic fungus Leptolegnia chapmanii on some biological parameters of the dengue vector Aedes aegypti. Journal of Insect Science, vol. 13, no. 1, pp. 22. https://doi.org/10.1673/031.013.2201.

PEREIRA, C.R., DE PAULA, A.R., GOMES, S.A., PEDRA JUNIOR, P.C.O. and SAMUELS, R.I., 2009. The potential of Metarhizium anisopliae and Beauveria bassiana isolates for the control of Aedes aegypti (Diptera: Culicidae) larvae. Biocontrol Science and Technology, vol. 19, no. 8, pp. 881-886. http://dx.doi.org/10.1080/09583150903147659.

PÉREZ, M., 2017. Evaluación del temefos y pyriproxifeno para el control de larvas de Aedes aegypti en condiciones de laboratorio. Horizonte Médico, vol. 17, no. 4, pp. 24-29. http://dx.doi. org/10.24265/horizmed.2017.v17n4.05.

PORTILLA, M., SNODGRASS, G. and LUTTRELL, R., 2017. Lethal and sub-lethal effects of Beauveria bassiana (Cordycipitaceae) strain NI8 on Chrysoperla rufilabris (Neuroptera: Chrysopidae). The Florida Entomologist, vol. 100, no. 3, pp. 627-633. http://dx.doi. org/10.1653/024.100.0321.

RAWAL, D., 2019. A review on different strategies used for biological control of mosquitoes. International Journal of Mosquito Research, vol. 6, no. 5, pp. 41-43. http://www.dipterajournal.com/pdf/2019/ vol6issue5/PartA/6-5-8-725.pdf

REYES-DE LATORRE, A., PEÑA-RANGEL, M.T. and RIESGO-ESCOVAR, J.R., 2012. Carbohydrate metabolism in drosophila: reliance on the disaccharide trehalose. In: C.F. CHANG, ed. Carbohydratescomprehensive studies on glycobiology and glycotechnology. Rijeka: InTech, pp. 318-338. http://dx.doi.org/10.5772/50633.

SCHOLTE, E.J., KNOLS, B.G., SAMSON, R.A. and TAKKEN, W., 2004. Entomopathogenic fungi for mosquito control: a review. 
Journal of Insect Science, vol. 4, pp. 19. http://dx.doi.org/10.1093/ jis/4.1.19. PMid:15861235.

SHOUKAT, R.F., FREED, S., AHMAD, K.W. and REHMAN, A., 2018. Assessment of binary mixtures of entomopathogenic fungi and chemical insecticides on biological parameters of Culex pipiens (Diptera: Culicidae) under laboratory and field conditions. Pakistan Journal of Zoology, vol. 50, no. 1, pp. 299-309. http:// dx.doi.org/10.17582/journal.pjz/2018.50.1.299.309.

SHOUKAT, R.F., ZAFAR, J., SHAKEEL, M., ZHANG, Y., FREED, S., $\mathrm{XU}, \mathrm{X}$. and JIN, F., 2020. Assessment of lethal, sublethal, and transgenerational effects of Beauveria bassiana on the demography of Aedes albopictus (Culicidae: Diptera). Insects, vol. 11, no. 3, pp. 178. http://dx.doi.org/10.3390/insects11030178. PMid:32168886.

TEJEDA-REYES, M.A., RODRÍGUEZ-MACIEL, J.C., ALATORRE-ROSAS, R., LAGUNES-TEJEDA, Á., VARGAS-HERNÁNDEZ, M. and SILVA-AGUAYO, G.I., 2018. A new methodology to evaluate entomopathogenic fungi and formulated insecticides to control adults of Aedes aegypti (Diptera: Culicidae). The Florida Entomologist, vol. 101, no. 3, pp. 511-514. http://dx.doi. org/10.1653/024.101.0311.

VALERO-JIMÉNEZ, C.A., DEBETS, A.J., VAN KAN, J.A., SCHOUSTRA, S.E., TAKKEN, W., ZWAAN, B.J. and KOENRAADT, C.J., 2014. Natural variation in virulence of the entomopathogenic fungus Beauveria bassiana against malaria mosquitoes. Malaria Journal, vol. 13, pp. 479. http://dx.doi.org/10.1186/1475-2875-13-479. PMid:25480526.

WYATT, G.R., LOUGHHEED, T.C. and WYATT, S.S., 1956. The chemistry of insect hemolymph: organic components of the hemolymph of the silkworm, Bombyx mori, and two other species. The Journal of General Physiology, vol. 39, no. 6, pp. 853-868. http://dx.doi.org/10.1085/jgp.39.6.853. PMid:13346040. 